\title{
The Impacts of Ongoing Health Crisis Caused by Novel Coronavirus "COVID-19" on the Economics of the Countries
}

\author{
Ghassan Al-Masbhi ${ }^{*}$, Fekri Dureab ${ }^{2}$ \\ ${ }^{1}$ School of Economics and Management, Nanjing University of Science \& Technology, Nanjing, China \\ ${ }^{2}$ Heidelberg Institute of Global Health, Heidelberg University, Heidelberg, Germany \\ Email: ^ghassanalmasbhi@njust.edu.cn
}

How to cite this paper: Al-Masbhi, G., \& Dureab, F. (2021). The Impacts of Ongoing Health Crisis Caused by Novel Coronavirus "COVID-19" on the Economics of the Countries. Open Journal of Social Sciences, 9, 454465.

https://doi.org/10.4236/jss.2021.99033

Received: August 19, 2021

Accepted: September 15, 2021

Published: September 18, 2021

Copyright $\odot 2021$ by author(s) and Scientific Research Publishing Inc. This work is licensed under the Creative Commons Attribution International License (CC BY 4.0).

http://creativecommons.org/licenses/by/4.0/

(c) (i) Open Access

\begin{abstract}
This study examines the impact of COVID-19 cases on GDP growth and Unemployment in developed countries represented by Germany, France, and Spain and developing countries represented by Mexico, Uruguay, Brazil, Turkey, and China. Various statistical tests were employed; ADF-Fisher Chi-Square for stationarity, Pedroni Cointegration test, Hausemn test, and panel granger causality test. The empirical results suggest that data from developed and developing countries are stationary at I (1). The Pedroni cointegration test revealed no long-run relationship between the dependent variables (Covid cases) and independent variables represented by GDP growth and Unemployment. The Hausman test showed that the fixed effect model is suitable for this study. The fixed effect model's estimation suggests that there is a positive and significant association between COVID-19 with unemployment rate and GDP growth in industrialized countries. However, in developing countries, the rise in COVID cases causes a decrease in GDP growth and Unemployment. The study contribution is critically significant for policymakers and scientists to set a plan for the comprehensive economic recovery for the world after the pandemic.
\end{abstract}

\section{Keywords}

COVID-19, Economic Impacts, Unemployment, Developed Economies, Developing Countries

\section{Introduction}

Coronavirus is an illness caused by SARS-COV-2 (Gorbalenya et al., 2020). It was named COVID-19 by the WHO, which derived from "corona disease 2019" 
the name was selected to avoid producing stigma in terms of geography, population, or animal association (WHO, 2019). Pandemic-19 is a frightful respiratory syndrome. It is known as coronavirus; the virus was discovered in 2019 in $\mathrm{Wu}$ han city Hubei province and spread worldwide. Many countries faced social and economic challenges. According to the latest real-time statistics from the World Health Organization (WHO), as of 18:28 CENTRAL European Summer Time on August 17, the total number of confirmed COVID-19 cases globally was $20,7784,507$, with a total of 4,370,424 deaths, and the number is increasing daily. Health systems were destroyed, many countries' economies are collapsing, and others are barely standing on their feet. The pandemic hit more than 200 countries, killing more than 3 million people until today worldwide.

Since the time corona was discovered in December 2019, the world has changed; the virus became an issue and took many people's lives. The disastrous consequences of the pandemic left countries to consider imposing lockdowns and enforcing social distancing policies to control the pandemic. January 30, 2020, the WHO declared the COVID-19 outbreak a global health emergency. On March 2020 , the world health organization (WHO) announced COVID-19 as a global pandemic, it was the first declaration of a pandemic since 2009 when H1N1 was introduced. The new merged disease affects health systems in different countries, and many countries cannot meet sufficient medical supplies to the patients in which cause fear, anxiety, stress, and depression (Rajkumar, 2020). The effect was not only psychological but also physical and economical. In the perspective of purchasing power, people are changing their buying attitudes and tend to use more online shopping, and the majority prefer to buy alternative products with low prices. In both cases, the purchasing power decreases as the number of COVID cases increases. Therefore, due to the expansion of COVID, 19 people are losing their interest in shopping by maintaining social distancing (Khan, 2020).

With the ongoing outbreak of COVID-19, health systems around the globe are at their worse. The collapse of health care systems in many countries is caused by unprepared prevention, failure in early detection of the virus, shortage in health supplies, exhaustion of health workers, and overwhelmed public hospitals. The majority of countries, such as Brazil and India and many others, are struggling to control the disease (Lorenz et al., 2020; The Lancet, 2020). Germany is one of the countries that enjoy a strong health system and effectively treated many of their confirmed cases (Müller et al., 2020). However, Germany's health system started to weaken after the second wave of the pandemic; Cancellor Merkel said that the virus spread is very high and the health system will reach its limit shortly.

Confirmed cases are increasing daily by big margins, the death toll is rising, and many businesses went bankrupt. People lost their jobs; many countries declare an economic crisis. While the world sees the pandemic spread, many countries face the immediate effects of the global pandemic on their economy. The COVID-19 is gradually dragging the economy of countries into recession. Many 
countries have witnessed a decline in economic activity and a rapid increase in Unemployment in a short time. Spain is from the countries that suffered from a financial crisis from 2008 to 2014 caused by the housing bubble and the accompanying of unsustainably high GDP growth. The country is still grappling with recovery since 2015; it has been struggling for the past years with debt. Another country that could be plunged into a deep recession is France. According to the national statistics institute, France's economy shrank by $13.8 \%$ due to the lockdown; the negative economic development resulted from shutting down essential activities in the country. As the COVID-19 spread worldwide, lockdowns were one reason for the collapses of businesses that play a significant role in the country's rising number of jobless people. Developed countries suffered from the spread of the pandemic, and emerging nations took their share of this virus. According to the United Nations Development Program (UNDP), developing countries could face an income loss of $\$ 220$ billion.

The International Monetary fund (IMF) reported that because of COVID-19, the world's economy is going through its worst turndown since the great depression in the 1930s. Oxfam International, in its report, predicted that half a billion people could be pushed into poverty as a result of the pandemic, COVID-19. As a response to the pandemic, precautionary measures were executed by airline companies and other manufacturing companies to prevent the spread of the virus among the people. Consequently, many countries are falling behind, and it will take them many years to recover. Therefore this research will mainly show the relationship between Corona cases with the GDP growth and Unemployment in both developing and developed countries. This paper is constructed in four main parts; first an introduction and objective of the study, methodology used in the paper, discussion and results and conclusion.

\section{The Objective of This Study and Questions}

Since many studies depended on descriptive analysis to show the impacts of COVID-19, this study used the statistical approach to determine the effects of the ongoing health crisis caused by Novel Coronavirus "COVID-19" on GDP growth and Unemployment in developed, developing countries. Furthermore, the study understands better the COVID-19 impacts on the nation's real economic growth and unemployment rate.

The key objectives of the study are;

1) To determine the significance of the Impact of COVID-19 on GDP growth in Developed, developing, and least developing countries.

2) To analyze whether there is a long-run effect of the rise of COVID-19 cases on the economic growth and Unemployment for developed and developing countries.

\section{Methodology}

\subsection{Study Design and Conceptual Framework}

This is a quantitative analytic study to identify the association of the COVID- 
19 cases with GDP growth and Unemployment in Developed countries (France, Germany, and Spain) and developing countries represented by Mexico, Uruguay, Brazil, Turkey, and China. This study used monthly basis panel data from January 2019 to December 2020 using a software package called Eviews. (Figure 1)

\subsection{Data Analysis}

In this study, several tests are taken to investigate the impact of corona on GDP growth in developing and developed countries. Unite root analysis, ADF test, Co-integration test, Granger Causality test, and the VAR Model. To investigate the impact of Corona virus cases on GDP growth and Unemployment, monthly panel data was collected from January 2019 to December 2020 using different databases such as Statista, World Bank, African development, and world-meter websites. For the developed countries, the study has 54 observations and 109 for Developing countries. The developed countries in this study are represented by (Germany, France, and Spain), while the developing countries are Mexico, Uruguay, Brazil, Turkey and China.

\subsection{Multiple Regression Model}

Regression model for developed countries and developing countries

$$
\text { LCOVID.V }=\beta 0+\beta 1 \text { LGDP }+\beta 2 \text { LUNEMP }+ \text { ui }
$$

LCOVID.V is the natural logarithm of COVID-19 in the reported countries.

$\beta 0=$ The intercept of Equation (1),

$\beta 1=$ The slope coefficient of GDP growth,

LGDP is the natural logarithm of GDP growth in the reported countries,

$\beta 2=$ The slope coefficient of Unemployment,

LUNEMP is the natural logarithm of GDP growth in reported countries, ui $=$ the error term of the equation.

\subsection{Unit-Root Test Results (ADF)}

- ADF-Fisher Chi-Square Test

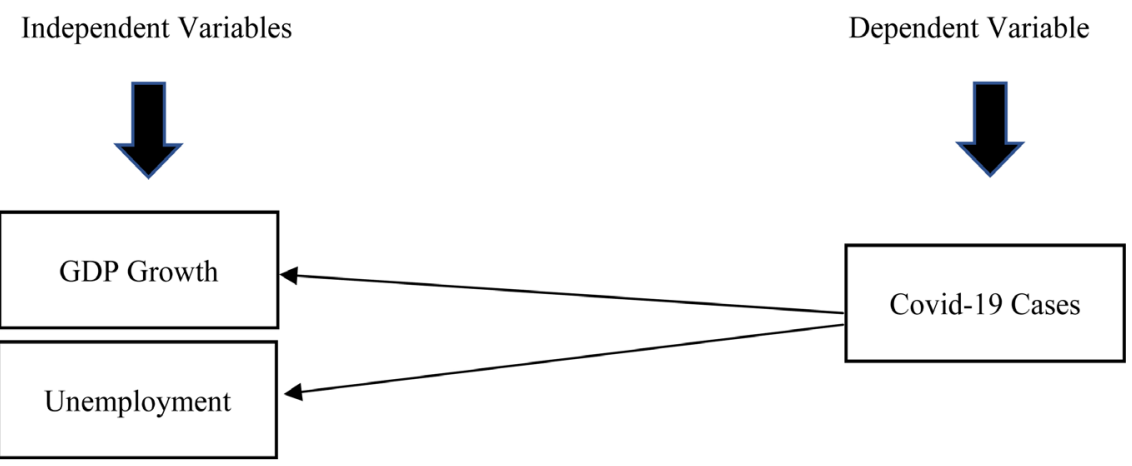

Figure 1. Proposed framework of the impact of COVID-19 cases on GDP growth and unemployment rate. 
The unit root test is an important econometric procedure to examine the data's stationarity; if the data is non-stationary, the $\mathrm{R}$ square will be high, which shows variables do not exist. When data is not stationary, it does not have economic meaning. Therefore, it is critical to investigate the stationarity of the data using the augmented dicky Fuller test. The null and alternative hypothesis The Null and alternative hypothesis are as follow

H0: $\delta=1$ unit root (Variables is not stationary),

H1: $\delta<1$ no unit root (Variable is stationary).

If the coefficient is less than one, then the hypothesis of $y$ contains a unit root is rejected. The rejection of the null hypothesis means the variables are stationary and have a unit root test; however, if it is one or more, we accept the null hypothesis, which means that variables have unit root and are not stationary.

\subsection{The Panel Cointegration Test}

The Pedroni cointegration test was first developed by Pedroni (2004). It was used to determine the cointegration between the variables in the panel data. Pedroni developed seven statistic tests to examine the panel cointegration between variables. There are two categories for the Pedroni test; the first group contains four tests within dimensions. The other group has three tests between dimensions (Asteriou \& Hall, 2007). The within dimension group termed as the panel cointegration statistics, and the between dimensions statistics are called group-mean cointegration statistics.

Pedroni test introduces seven tests that examine the null hypothesis of no cointegration. These seven tests allow heterogeneity in the panel in the short and long run. According to Güvenek and Alptekin (2010), the Pedroni test permits the effects between the cross-section of the panel to be different. Additionally, it also allows the differentiation of the cross-section of the cube under the alternative hypothesis.

\subsection{Fixed Effect Model vs. Random Effect Model}

The fixed effect model is a statistical model in which the values of independent variables do not change (constant) while the dependent variable value changes as a response to the independent ones. According to Allison (2009), the unobserved variables in the fixed effects model have a relationship with observed ones. $\mathrm{He}$ added that the constant variables are not estimated; however, they should be controlled. On the other hand, with the random-effects model, variables tend to have no association with observed variables. Nevertheless, the Random effects model can be desirable in some cases.

\subsection{Hausman Test}

The Hausman (1978) Test is conducted in this study in order to choose between the fixed effect model or the random effect model. The null hypothesis of the Hausman test suggests that the random-effects model is appropriate. In contrast, 
the alternative hypothesis indicates the suitability of using the fixed effects model.

\subsection{Granger Causality Test}

According to Gujarati and Porter (2009), Granger causality is a hypothesis test to determine whether one variable helps in predicts another one. For example, suppose A granger causes B. In that case, it means that A contributes to forecasting $B$. Additionally, the granger causality test shows and explains the association between the dependent and independent variables.

\section{Discussion and Results}

\subsection{ADF-Fisher Chi-Square for Stationarity}

Table 1 shows the stationarity of the data in both developing and developed countries. After conducting the ADF Fisher Chi-square test, it can be noticed that in developed countries and developing countries, variables were only stationary at first difference. However, GDP growth showed stationarity in both I (0) and I (1). The p values of all variables are less than the $10 \%$ significance; therefore, we reject the null hypothesis and declare the stationarity of the data. Therefore the data results are consistent and reliable

\subsection{Pedroni Cointegration Test}

From the panel Pedroni cointegration results; Table 2 suggests only one out of the seven statistics reject the null hypothesis of no cointegration and imply the variables are cointegrated. However, six of the seven statistics fail to reject the null hypothesis of no cointegration. These six tests are Panel rho test, Panel P.P. statistic, Panel ADF test, Group rho test, Group PP-stat and Group ADF-Stat. Since most tests imply no cointegration, it is concluded that there is no cointegration between the variables. In other words, COVID-19 does not have an impact on Unemployment and GDP growth in the long run in both developing and developed countries.

\subsection{Hausman Test}

By conducting the Hausman test to determine which model to use; fixed effect

Table 1. ADF-Fisher chi-square.

\begin{tabular}{|c|c|c|c|c|c|c|c|c|}
\hline \multirow{3}{*}{ Variables } & \multicolumn{4}{|c|}{ Developed Countries } & \multicolumn{4}{|c|}{ Developing countries } \\
\hline & \multicolumn{2}{|c|}{ I (0) } & \multicolumn{2}{|c|}{ I (1) } & \multicolumn{2}{|c|}{ I (0) } & \multicolumn{2}{|c|}{ I (1) } \\
\hline & Intercept & $\begin{array}{l}\text { Trend \& } \\
\text { Intercept }\end{array}$ & Intercept & $\begin{array}{c}\text { Trend and } \\
\text { intercept }\end{array}$ & Intercept & $\begin{array}{c}\text { Trend \& } \\
\text { Intercept }\end{array}$ & Intercept & $\begin{array}{c}\text { Trend \& } \\
\text { Intercept }\end{array}$ \\
\hline Covid Cases & 4.73212 & 5.66094 & $17.1678^{* * *}$ & $18.4365^{* * *}$ & 8.22090 & 8.22090 & $34.5253^{* * *}$ & $31.1017^{* * *}$ \\
\hline GDP Growth & $19.3273^{* * *}$ & $11.9150^{*}$ & $20.9470^{\star * *}$ & $13.1196^{* *}$ & $31.4606^{* * *}$ & $24.1996^{* * *}$ & $28.8611^{* * *}$ & $17.2621^{\star}$ \\
\hline Unemployment rate & 3.67110 & 4.24719 & $19.1109^{* * *}$ & $12.2591^{\star}$ & 8.49257 & 12.3499 & $36.7719^{* * *}$ & $28.0557^{* * *}$ \\
\hline
\end{tabular}

${ }_{* * *}$ denote that rejection of null hypothesis at 0.01 significant level. 
Table 2. Padroni cointegration test.

\begin{tabular}{|c|c|c|c|c|c|c|c|}
\hline \multicolumn{5}{|c|}{ Developed Countries } & \multicolumn{3}{|c|}{ Developing Countries } \\
\hline & & $\begin{array}{l}\text { Individual } \\
\text { Intercept }\end{array}$ & $\begin{array}{l}\text { Trend and } \\
\text { Intercept }\end{array}$ & $\begin{array}{c}\text { No Trend } \\
\text { and no intercept }\end{array}$ & $\begin{array}{c}\text { Individual } \\
\text { Intercept }\end{array}$ & $\begin{array}{l}\text { Trend and } \\
\text { Intercept }\end{array}$ & $\begin{array}{c}\text { No Trend } \\
\text { and no intercept }\end{array}$ \\
\hline & Panel Test & T-Stat & T-Stat & T-Stat & T-Stat & T-Stat & T-Stat \\
\hline \multirow{7}{*}{$\begin{array}{c}\text { Pedroni } \\
\text { Cointergartion } \\
\text { Test }\end{array}$} & Pane v-Stat & $1.671598^{\star *}$ & $2.284257^{\star *}$ & $1.671598^{\star *}$ & $1.580775^{\star}$ & $1.663160^{* *}$ & 0.128708 \\
\hline & Panel rho-Stat & 2.141385 & 1.236345 & 2.141385 & 0.854642 & 1.868318 & 0.471027 \\
\hline & Panel pp-Stat & 3.808782 & 2.394778 & 3.808782 & 1.408440 & 2.682553 & 0.720075 \\
\hline & Panel ADF -Stat & 1.842974 & $-1.442411^{*}$ & 1.842974 & 2.988357 & $-3.436450^{* * *}$ & 2.104624 \\
\hline & Group rho-Stat & 3.664736 & $2.162138^{\star *}$ & 3.664736 & 1.344780 & 1.663160 & -1.300591 \\
\hline & Group PP-Stat & 6.746518 & 3.636954 & 6.746518 & 1.801023 & 1.868318 & 1.334551 \\
\hline & Group ADF-Stat & 3.286623 & 0.720643 & 3.286623 & 1.734769 & 2.682553 & 3.192017 \\
\hline
\end{tabular}

model or random-effect model. The null hypothesis states that the random effect model is preferred, while the alternative hypothesis indicates that the Fixed effects model is more appropriate. According to Table 3, the P-value in both developing and developed countries is less the $1 \%$. Therefore we reject the null hypothesis and accept the alternative hypothesis. It can be concluded that the Fixed effects model is suitable to carry on in this study.

\subsection{Fixed Effects Model}

According to the fixed effects model (Table 4), it is noticed that Unemployment and GDP share a positive relationship with COVID-19 cases since the $p$-value of both variables is less than $5 \%$ and both of the coefficients are positive for GDP and Unemployment with 20,495.24 and 337,041.6, respectively in Developed countries. On the other hand, in developing countries, GDP shares a negative and insignificant relationship with COVID-19 cases since the $p$-value of both variables is more than $5 \%$. However, with $p$-values less than $1 \%$, Unemployment shares a positive and significant relationship with COVID-19 cases. In a similar study, Aycock and Chen (2021b) investigate the impact of economic development and the spread of COVID-19; results showed that there is a positive correlation between economic growth and COVID-19 in U.S. and some European countries. Aycock and Chen (2021b) suggested a higher level in economic growth contributing to the spreading of COVID-19 and infectious diseases. Sira and Woldetensay (2020) carried out a study on the impact of COVID-19 on Unemployment and GDP growth in Ethiopia; they concluded that COVID-19 contributes to the increase of Unemployment and a decrease in GDP growth.

\subsection{Granger Causality Test}

The causality test is performed to find out the association between the variable. The results indicate the presence of bi-directional and unidirectional causality between the variables. The study results in developed countries suggested that 
Table 3. Hausman test.

\begin{tabular}{lcccccc}
\hline \multicolumn{6}{c}{$\begin{array}{c}\text { Correlated Random Effects-Hausman Test } \\
\text { Test cross-section random effects }\end{array}$} \\
\hline \multicolumn{5}{c}{ Developed Countries } & \multicolumn{5}{c}{ Developing Countries } \\
\hline Test Summary & Chi-Sq. Statistic & Chi-Sq. d.f. & Prob. & Chi-Sq. Statistic & Chi-Sq. d.f. & Prob \\
\hline $\begin{array}{c}\text { Cross-section } \\
\text { random }\end{array}$ & 20.617051 & 2 & 0.0000 & 17.982556 & 2 & 0.0001 \\
\hline
\end{tabular}

Null Hypothesis: Random-effects model appropriate; Alternative Hypothesis: Fixed Effects Model appropriate.

Table 4. Fixed effects model.

\begin{tabular}{ccccccccc}
\hline \multirow{2}{*}{ Variable } & \multicolumn{3}{c}{ Developed Countries } & \multicolumn{4}{c}{ Developing Countries } \\
\cline { 2 - 9 } & Coefficient & Std. Error & t-Statistic & Prob. & Coefficient & Std. Error & t-Statistic & Prob. \\
\hline C & $-9,713,040$ & $2,038,377$ & -4.765086 & 0.0000 & $-1,270,468$ & $357,442.9$ & -3.554324 & 0.0005 \\
GDP & $20,495.24$ & $10,111.95$ & 2.026834 & 0.0467 & -2277.357 & 3747.584 & -0.607687 & 0.5446 \\
UNEM & $337,041.6$ & $71,656.81$ & 4.703553 & 0.0000 & $51,729.50$ & $12,719.28$ & 4.067014 & 0.0001 \\
\hline
\end{tabular}

there is bidirectional causation that runs from COVID-19 cases to GDP and vice versa. Additionally, a unidirectional association runs from Unemployment to COVID19 since the P-value is less than the $5 \%$ significance. Furthermore, findings show that COVID-19 does not help in forecasting unemployment. However, in developing countries, we can conclude that neither GDP nor Unemployment contributes to forecasting the COVID-19 and vice versa. (Table 5)

\section{Discussion}

\subsection{The Relationship between COVID-19 and GDP Growth in Developed and Developing Countries}

The empirical findings from the developed countries show that there is a positive and significant association of COVID-19 cases with GDP growth; the result of this study is consistent with Aycock and Chen (2021b) and Aycock and Chen (2021a). The study suggests that developed countries with higher level of GDP growth are more risky in facilitating infectious disease spread due to advanced transportation. In developed countries, people normally tend to live in large cities where they move from a place to another easily through the abundant transportation tools. Furthermore, the symptoms of COVID-19 might appear after two weeks, and in some cases, infected people might not develop any symptoms at all. This made the virus to be transmitted without even knowing through moving from a place to another. Moreover, developed countries have the capacity to detect cases and register them due to strong surveillance systems and the capacity for testing-also, awareness of people to seek health services better than developing countries. Additionally, people who live in developed countries enjoy high living standards that allow them to do activities, travel around, and attend concerts, increasing their chances of being infected. 
Table 5. Granger causality test.

\begin{tabular}{ccccccc}
\hline & \multicolumn{3}{c}{ Developed Countries } & \multicolumn{3}{c}{ Developing countries } \\
\cline { 2 - 7 } Null Hypothesis: & Observation & F-Statistic & Prob. & Observation & F-Statistic & Prob. \\
\hline $\begin{array}{c}\text { CORONA does not } \\
\text { Granger Cause UNEM }\end{array}$ & 54 & 1.85144 & 0.1129 & 109 & 2.15005 & 0.1216 \\
$\begin{array}{c}\text { UNEM does not } \\
\text { Granger Cause CORONA }\end{array}$ & 54 & 3.02671 & 0.0153 & 109 & 0.3420 & 1.08421 \\
$\begin{array}{c}\text { GDP does not } \\
\text { Granger Cause UNEM }\end{array}$ & 54 & 2.37133 & 0.0466 & 109 & 15.4571 & $1 . \mathrm{E}-06$ \\
$\begin{array}{c}\text { UNEM does not } \\
\text { Granger Cause GDP }\end{array}$ & 54 & 2.13563 & 0.0697 & 109 & 0.6014 & 0.51102 \\
$\begin{array}{c}\text { GDP does not } \\
\text { Granger Cause CORONA }\end{array}$ & 54 & 4.11961 & 0.0025 & 109 & 0.6413 & 0.44622 \\
$\begin{array}{c}\text { CORONA does not } \\
\text { Granger Cause GDP }\end{array}$ & 54 & 4.42324 & 0.0016 & 109 & 0.02235 & 0.9779 \\
\hline
\end{tabular}

On the other hand, developing countries and low-income countries are in a difficult position to respond to the COVID-19 crisis. The study suggests that when COVID-19 cases increase in developing countries, economic growth decreases and countries' income becomes less and less. Developing and emerging countries are in a vulnerable position even before the COVID-19 crisis; many countries are in public debt and barely standing on their feet. After imposing a lockdown in many countries, exports and imports declined, businesses shut down, and airline companies lost a significant amount of money. The united nation conference on trade and development (UNCATAD) predicted that developing countries are threatened to lose 850 billion export revenue due to the COVID-19 crisis. The international community is the key the help developing nations to contain the virus by providing priorities such as health supplies, food, medicines, and vaccines. As a result of the collapsing economies, the international monetary fund provided funding to many developing countries by establishing long-term economic programs to help the economic sustainability for developing countries.

Furthermore, the study suggests that there is no long-run association of COVID-19 with GDP growth and Unemployment. Ozparlak (2020) studied the impact of COVID-19 on economic variables; his findings show that Italy and France and the USA have no long-term relationship with COVID-19 cases. The effects of the pandemic, in the long run, will depend on the response of the country. The expected scares will vary depending on the economy's structure and authorities' policy response (Jackson et al., 2020). China has enjoyed a fast recovery as the pandemic became under control; the domestic market had a quick recovery by $80 \%$ of the pre-crisis (Czerny et al., 2021). Additionally, it also witnessed a strong rebound comparing to the first quarter in 2020. 
Nevertheless, Europe, on the other side is struggling to recover from the impact of the COVID-19 crisis. According to Wijffelaars (2020), Spain could not fully control the second wave of the spread of the virus, which remarkably had a huge impact on tourism as it accounted for $15 \%$ of the country's GDP. From both cases, it can be concluded that the economic recovery is based on the speedy control of the pandemic. Therefore with limited healthcare in emerging countries, the impact will be more severe in developing countries than the developed ones.

\subsection{The Relationship between COVID-19 with Unemployment in Developed and Developing Countries}

Statistically, the study suggests that due to the increase of COVID-19 cases, demand for labor shrank to its lowest level, causing a rapid increase in the unemployment rate worldwide. During the COVID-19 pandemic, Unemployment was a problem for both developing and developed countries. Many people lost their jobs, especially after enforcing the lockdown and taking containment measures. Social distancing and movement restrictions force many small and medium businesses to collapse and shut them down. Low-income countries' risks are not limited to the higher unemployment rate and withheld wages. However, also it could fall deep into hunger and long-lasting poverty. Therefore Policymakers and authorities should implement fiscal and monetary policies to help in the global economic recovery. Governments should provide industries with financial aid and remit them from a proportion of tax income. National banks should adopt an expansionary monetary policy by lowering the interest rate to encourage investors to invest, consumers to spend, and businesses to achieve profits.

International Monetary Fund (IMF, 2020) stated that COVID-19 is the storm that destroyed jobs, worsening poverty, and creating debt, especially for countries and firms in vulnerable situations. This economic disruption will leave scars in the long run. However, as the study suggests, there will not be certain longrun effects of the COVID-19 cases on Unemployment. With the availability of vaccination, many countries started to ease restrictions, leading to restaurants and small businesses opening to employ many people who lost their jobs during the pandemic. The latest data show that $50 \%$ of the U.S. population received at least one dose.

Consequently, employment improves faster and the employment level would be back to the pre-pandemic level by mid-2021 (Davidson, 2021). Another case is Australia; it was reported that in February 2021, employment would be back to its normal state in the pre-pandemic level (Edwards, 2021). In short, the COVID-19 will not have long scares on employment as many countries are recovering and expected to enjoy pre-pandemic level shortly.

\section{Recommendation}

Covid-19 is still prevalent worldwide and has mutated into delta virus, cases are still increasing therefore data always changes throughout the time. 


\section{Conclusion}

This research examines the factors impacts of COVID-19 cases on the GDP growth and unemployment in selected developing and developed countries. Monthly panel data was collected from January 2019 to December 2020. The study results revealed a positive and significant correlation between Covid-19 cases with the economy growth and unemployment of developed countries. Technology and advanced transportation are some of the main factors that lead to increased cases. In developed countries, health supplies are more efficient to record cases daily, while other emerging countries have a weak healthcare system and find it hard to detect viruses on time. On the other hand, in developing countries, the rise of COVID-19 causes a decline in GDP growth and increases unemployment. As COVID cases increase, governments impose lockdown policies and social distancing measures, resulting in shutting down businesses and companies.

Consequently, in developed countries, people lose their jobs and become unemployed, while in the emerging economies, the consequences could push many people under the poverty line. The research also suggests there will not be a longrun effect of COVID in the future of global economies. As vaccinations started to roll out, many countries will witness economic recovery by the end of 2021 .

\section{Conflicts of Interest}

The authors declare no conflicts of interest regarding the publication of this paper.

\section{References}

Allison, P. D. (2009). Fixed Effects Regression Models. Sage. https://doi.org/10.4135/9781412993869

Asteriou, D., \& Hall, S. G. (2007). Applied Econometrics: A Modern Approach (Revised ed.). Palgrave Macmillan.

Aycock, L., \& Chen , X. (2021a). Levels of Economic Development and the Spread of Coronavirus Disease 2019 (COVID-19) in 50 U.S. States and Territories and 28 European Countries: An Association Analysis of Aggregated Data. Global Health Journal, 5, 24 30. https://doi.org/10.1016/i.glohj.2021.02.006

Aycock, L., \& Chen , X. (2021b). Levels of Economic Growth and Cross-Province Spread of the COVID-19 in China. Journal of Epidemiology and Community Health, 75, 824828. https://doi.org/10.1136/jech-2020-214169

Czerny, A. I., Fu, X., Lei, Z., \& Oum, T. H. (2021). Post Pandemic Aviation Market Recovery: Experience and Lessons from China. Journal of Air Transport Management, 90, Article ID: 101971. https://doi.org/10.1016/j.jairtraman.2020.101971

Davidson, P. (2021, February 1). Economy Will Return to Pre-Pandemic Output Level by Mid-2021, Sooner than Expected, CBO Predicts. USA Today.

https://www.usatoday.com/story/money/2021/02/01/unemployment-economy-returnpre-COVID-level-mid-2021/4342660001/

Edwards, J. (2021). Covid Recovery, in Australia and the World. Lowy Institute. https://www.lowyinstitute.org/the-interpreter/COVID-recovery-australia-and-world

Gorbalenya, A. E., Baker, S. C., Baric, R. S., de Groot, R. J., Drosten, C. et al. (2020). Severe 
Acute Respiratory Syndrome-Related Coronavirus: The Species and Its Viruses-A Statement of the Coronavirus Study Group. Nature Microbiology, 5, 536-554.

Gujarati, D. N., \& Porter, D. C. (2009). Essentials of Econometrics (4th ed.). Douglas Reiner.

Güvenek, B., \& Alptekin, V. (2010). Energy Consumption And Economic Growth: A Panel Data Analyses for Oecd Countries. Enerji, Piyasa Ve Düzenleme, 1, 172-193.

Hausman, J. A. (1978). Specification Tests in Econometrics. Econometrica, 46, 1251-1272. https://doi.org/10.2307/1913827

IMF (International Monetary Fund) (2020, March 23). The Great Lockdown: Worst Economic Downturn Since the Great Depression.

https://www.imf.org/en/News/Articles/2020/03/23/pr2098-imf-managing-director-stat ement-following-a-g20-ministerial-call-on-the-coronavirus-emergency

Jackson. J. K., Weiss, M. A., Schwarzenberg, A. B., \& Nelson, R. M. (2020). Global Economic Effects of COVID-19. Report No. R46270, Congressional Research Service.

Khan, N. (2020). Critical Review of COVID-2019 in Pakistan and Its Impact on Pakistan Economy. https://doi.org/10.2139/ssrn.3629718

Lorenz, C., Azevedo, T. S., \& Chiaravalloti-Neto, F. (2020). COVID-19 and Dengue Fever: A Dangerous Combination for the Health System in Brazil. Travel Medicine and Infectious Disease, 35, Article ID: 101659. https://doi.org/10.1016/j.tmaid.2020.101659

Müller, O., Ju, G., Jahn, A., \& Razum, O. (2020). COVID-19 Control: Can Germany Learn from China? International Journal of Health Policy and Management, 9, 432-435. https://doi.org/10.34172/ijhpm.2020.78

Ozparlak, G. (2020). Long Run and Short Run Impacts of COVID-19 on Fincancial Markets. Journal of Business, Economics and Finance, 9, 155-170. https://doi.org/10.17261/Pressacademia.2020.1221

Pedroni, P. (2004). Panel Cointegration: Asymptotic and Finite Sample Properties of Pooled Time Series Tetsts, with an Application to the PPP Hypothesis. Econometric Theory, 20, 597-625. https://doi.org/10.1017/S0266466604203073

Rajkumar, R. P. (2020). COVID-19 and Mental Health: A Review of the Existing Literature. Asian Journal of Psychiatry, 52, Article ID: 102066.

https://doi.org/10.1016/j.ajp.2020.102066

Sirah, S. E., \& Woldetensay, A. W. (2020). Effect of Covid-19 Pandemic on Unemployment Rate and Economic Growth: The Case of Ethiopia. Research on Humanities and Social Science, 10, 10-18.

The Lancet (2020). India under COVID-19 Lockdown. Lancet, 395, 1315. https://doi.org/10.1016/S0140-6736(20)30938-7

WHO (World Health Organization) (2019). Coronavirus Disease. https://www.who.int/emergencies/diseases/novel-coronavirus-2019

Wijffelaars, M. (2020). Spain's Struggle against COVID-19 Hampers Its Economic Recovery. Rabobank.

https://economics.rabobank.com/publications/2020/october/spains-struggle-against-C OVID-19-hampers-its-economic-recovery/ 